\title{
Chapter 6 \\ Silvopastoral Systems in Portugal: \\ Current Status and Future Prospects
}

\author{
M. Castro
}

\begin{abstract}
Portugal has a high diversity of agroforestry systems like other Mediterranean countries. This is the result of the Mediterranean climate, great variability of bioclimatic conditions, a long history of land use, and a marked variation in land tenure between north and south of the country. Four major silvopastoral systems are described: two classically Mediterranean - montado and Olive tree system, and two typically of the transitional environment between Mediterranean and Temperate conditions - Pyrenean oak and Chestnut systems. Some products of traditional agroforestry systems such as charcoal, organic manure, livestock production and others have become less valuable with the socio-economic transformation of the 1960s. These systems have been declining from approximately 1950 onwards. Currently, the focus on sustainable agriculture, with greater emphasis on nature and landscape conservation, has meant that environmental values now represent new opportunities for income generation from these systems. A better understanding of traditional agroforestry systems is needed for the formulation of a specific European policy that will preserve European landscapes. This paper looks at the future potential for silvopastoral systems in Portugal based on current status.
\end{abstract}

Keywords Pyrenean oak system, chestnut systems, olive tree system, montado, Portugal

\section{Introduction}

The countries of the Mediterranean basin are characterized by climatic variability fluctuations and unpredictability (particularly rainfall), leading to bimodal growth patterns (Gómez-Sal 2000b). These conditions have directly influenced the land use systems, and indirectly the character of the Mediterranean people (San-Miguel et al. 2002).

\footnotetext{
Escola Superior Agrária de Bragança, Apartado 172, 5301-855 Bragança, Portugal

Corresponding author: e-mail: marina.castro@ipb.pt
} 
The Mediterranean region has also had a long history of human land use. In this interactive process, the human-induced transformations shaped the landscape, modifying plant and animal communities, the genetic make up of individuals, races and ecotypes. Human adaptation leads to differentiated land use systems and forms of resource exploitation. Among these, multi-purpose uses like agroforestry occupy a place of major importance in this region.

Under unpredictable conditions, the diversification of agricultural production is essential. This and the low economic viability of wood and crop productions, these main features contribute to explaining the traditional multi-purpose land uses of the Iberian Peninsula.

The climate can be seen as a modeler of character of a people with high creativity and adaptive ability. As a result, there is a high diversity of landscapes and land use systems, some of them with high complexity and sustainability (Castro 2004a).

Portugal is located at the south-western end of the Iberian Peninsula $\left(37^{\circ}-42^{\circ} \mathrm{N}\right.$ latitude and $6^{\circ}-9^{\circ} 30^{\prime} \mathrm{W}$ longitude), with a small land area (continental area of $88.796,7 \mathrm{~km}^{2}$ ), but a high bioclimatic variability. Rainfall ranges from $400 \mathrm{~mm}$ (south of river Douro at Province of Beira Interior) to 3,000 mm (northwest region, the Province of Minho, influenced by the Gulf stream) (INMG 2006). The climate is of a Mediterranean type, controlled by the Atlantic influence on the north coast, and the continental influence of the Iberian Peninsula, in the centre. Mountains dominate the northern region (north of the river Tejo) and obstruct the moisture flow from the Atlantic to the inner regions of Portugal.

Associated with climatic conditions, timber production occurs with no silvoarable activity in the northern and central littoral, based on Pinus pinaster Ait. and Eucalyptus globulus Labill. In the south and north interior region, forestry production is limited by drought or cold, and agroforestry systems are common.

The agroforestry systems, or their practices, take place all over the Mediterranean basin with historic references over the centuries. The Celtic civilization made use of systems like montado, and the Visigoths regulated the use of pasture lands and "montanheira" (San-Miguel et al. 2002). Nair (1993) describe s livestock in olive and orange orchards in Roman times. Even in the last century in some rural areas, people used to make bread from acorn flour. This human consumption of acorns was widespread in the Quercus growing regions. Some authors believe that Castanea sativa Mill. was introduced into Portugal by Romans to feed slaves working in the mines.

As the result of biophysical conditions and historical colonization of the territory of Portugal, different agroforestry systems were established with marked differences relating to different land use patterns between north and south: small and scattered properties are normal in the north, and large properties predominates in the south.

A closed system called montado was developed in the south, but open fields involving several landscape components were developed in the north. Etienne (1996) considers that different components make up an agroforestry system and its spatial sequences have an ecological and economic meaning if interactions among them are maintained. De Miguel (1999) describes an agrosilvopastoral system in the Basque Country - Caserio - as the result of different components of the 
landscape. As far as this author was concerned, the system is the entire landscape of this region.

Based on our research and others, this paper intends to demonstrate and analyse and functioning respectively the diversity of silvopastoral systems found in Portugal. This information will be useful in making a case for their preservation. Four types of silvopastoral systems are described: the Olive tree system, the montado system, the chestnut system and the Pyrenean oak system. This last system will be more extensively dealt with as the author is familiar with its operation, its singular importance in the region, and its characteristics exclusive to the transitional environment of the Iberian Peninsula.

Other systems, like the Stone Pine system (Pinus pinea L.) and bocage are only listed, as the literature on them is inconsistent. The Stone Pine occurs in the Setubal Peninsula (south of Lisbon) and is mainly exploited for pine nuts. The bocage system - Ash trees and other riparian trees planted in lines or scattered through meadows - occurs in the Trás-os-Montes Province (northeast of Portugal). The trees, in addition to providing timber, are used in summer as fodder and for shelter by livestock.

\section{Description of Systems}

\section{Pyrenean Oak System}

\section{Location}

Pyrenean oak (Quercus pyrenaica Willd.) is one of the most abundant and characteristic oak species in the Iberian Peninsula (Calvo et al. 2003). It is a deciduous transitional Mediterranean oak, which is restricted to SW Europe (west-northwest Spain, southwest France and northeastern Portugal) and some isolated sites in northern Morocco. Pyrenean oak occurs where there is a transition between typical Mediterranean sclerophyllous and temperate deciduous forests (Tarrega et al. 2006).

Pyrenean oak is mainly found in the form of coppices or young forests. Oak forest system covers about 60,000 ha in Spain (Santa Regina 2000) and 62,000 ha in Portugal (Carvalho 1995). In Portugal, the main areas covered by this species are found in the northeast in particular in the Bragança region (Franco 1956), where they cover about $40 \%$ of the total forest area use. According to (Correia 1993), Pyrenean oak can also be found in some localised areas of the Alentejo region (southern Portugal) in the form of montado, where the average precipitation is relatively high due the influence of topography.

In the Bragança region ( $41^{\circ} 46 \mathrm{~N}$ latitude and $6^{\circ} 45^{\prime} \mathrm{W}$ longitude), where the Pyrenean oak is most widespread in Portugal, the climate is mainly sub humid Mediterranean. The average annual temperature is $11.9^{\circ} \mathrm{C}$ and average rainfall ranges from 741 to $1,385 \mathrm{~mm}$ per year, according to altitude, mainly from October to May 
(INMG 1991). The dry period occurs mainly in July and August. The soils, derived from schist or granite, are mainly characterised by their acidity and low productive capacity. The dominant soils are umbric Leptosols and dystric Leptosols.

\section{Past Experience and Future Prospects}

Throughout historical times, oak woodlands held a prominent place within the economy of Mediterranean regions by providing firewood, charcoal, by-products such as tannin, and by offering an important grazing area for livestock (Debussche et al. 2001). There was a continuous transfer of fertility from woods to cultivated land from animal manure and this helped make these areas successful for agriculture in the past.

After World War II, considerable socio-economic changes occurred in Mediterranean countries (Papanastasis 2004). In southern Europe, there was a massive migration movement of people from the rural areas. In Portugal, this movement increased due to the Colonial Wars in Africa and increased the afforestation rate of common lands (Baldios) by the State. These changes lead to the abandonment and simplification of agricultural processes, with poor connectivity between agriculture, forestry and animal husbandry. Also, the indigenous forests have been frequently replaced by coniferous species like Pinus pinaster, considered to be more highly productive from a forestry point of view. Under these conditions, there has been a marked decline in the use of multipurpose systems, such as those where the tree cover is Pyrenean oak.

The focus in Europe mow is on sustainable agriculture and conservation of wildlife and natural landscapes. Fortunately, modern social needs trends have increased people's awareness of environmental values. This situation creates a new opportunity for traditional silvopastoral systems, like the Pyrenean oak coppices.

This oak silvopastoral system produces firewood, fodder and welfare for traditionally managed flocks of small ruminants. Also it maintains a diverse landscape and a high biodiversity. It is seen as a strategic ecosystem for nature conservation as it maintains resources in a sustainable and productive way (Gómez-Sal 2000b). The high commercial value of firewood and the environmental needs of a more affluent European population all add to the potential value of this emerging resource.

In modern Europe, agriculture and forestry only exist in their present forms because they are to some extent maintained by subsides (Eichhorn et al. 2006). To maintain this oak system therefore and the landscape associated with it, special measures should be taken at different decision levels. According to Papanastasis (2004) the agri-environment measures currently implemented in the European Union countries should be adapted to also include these systems to ensure their conservation and sustainability values.

\section{Characterisation of the System and Its Utilisation}

In Trás-os Montes region, the landscape is characterised by a patchwork of different types of land use. Small livestock production is based on grazing patterns on 
different fields or vegetation areas. In this mosaic-like landscape, each area has a particular function for the animals.

Pyrenean oak coppice is a landscape component along with other forms of land uses like scrublands, pasturelands and annual crops. Unlike the silvopastoral systems in southern Portugal, the Pyrenean oak coppices represent a small proportion of the territory of the villages, named 'touças'. These coppices are not used by flocks under private control as would be found in closed silvopastoral systems, but are held and managed communally.

Pyrenean oak coppices are characterized by the presence of a tree layer, planted at densities between 400 and 1,100 stems per hectare depending on the use and age. The understory is dominated by oak regeneration and to a lesser extent by shrubs such as Cytisus spp., Erica spp. and Genista falcata Brot. The herbaceous layer is scarce due to leaf fall and tree shading. Herbage production is from $570-2,500 \mathrm{~kg}$ DM ha ${ }^{-1}$ year $^{-1}$ (Castro 2004b).

In the past, the traditional coppice cycle of oak woodlands was very short, about 10-20 years depending on the region. Debussche et al. (2001) refers to coppice cycles of about 15-20 years, and Corcuera et al. 2006 to 10-15 years. Current cycles are longer than 20-25 years. The wood obtained during the felling operation is sold as firewood, the main commercial use and the woodlands are not generally managed conventionally. Pyrenean oak woodlands significantly improve local economic and social values by facilitating stock grazing. These forests provide forage and enhanced welfare to small ruminants (Castro et al. 2000a, b). Trees have a direct value as a fodder crop, providing acorns in autumn and leaves mainly in summer.

Contrary to other Quercus species, namely those found in the montado, Pyrenean oak regenerates easily producing abundant vegetative shoots, when felled. Grazing herbivores reduce biomass and vegetation cover of the herb and shrub layers and also reduces tree regeneration. Animals also play an important role in increasing soil fertility (Gómez-Sal 2000a).

Traditionally, the most common animals were indigenous goat and sheep breeds (Serrana and Churra Galega Bragançana). Currently, some shepherds cut tree branches to feed to the kids in winter. However, this practice is of no advantage to the trees because the commercial product from the coppice is firewood.

To increase acorn and understory herbaceous production, silvicultural practices such as pruning and thinning can be applied on the trees. These will improve conditions for the animal component in these systems. The introduction of pigs is another interesting proposition that needs to be considered. The Iberian pig is a native breed indigenous to the Iberian Peninsula. Their adaptation to the local environment and the high quality of its products has enhanced the persistence of the breed and the productive system it supports (Lopez-Bote 1998). The introduction of the Iberian pig to Pyrenean oak coppices could be of interest from an ecological and economical point of view.

In Portugal, Pyrenean oak woodlands are traditionally thought of as systems with multiple uses, but Castro (2004b) considers them as silvopastoral systems because of the important role played by the animals, in providing benefits to the trees and interacting with the trees (Fig. 6.1). 


\section{Components of system: trees/anima1s}
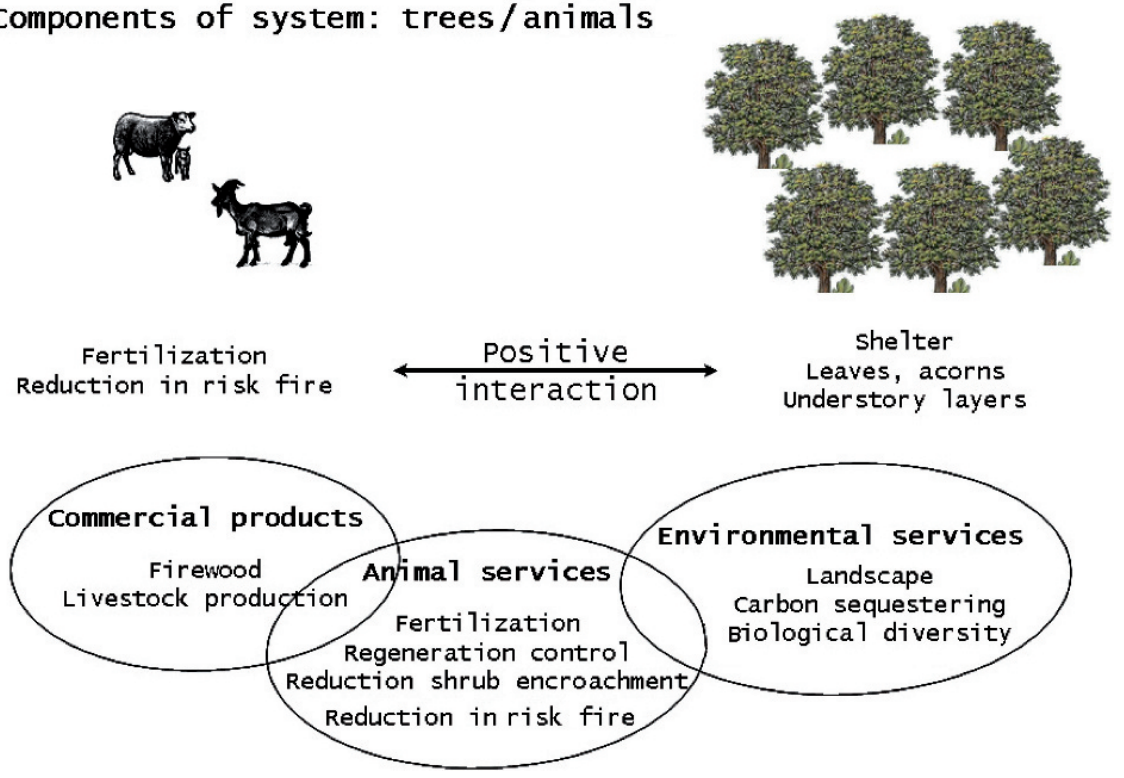

Fig. 6.1 Products and services offered by the Pyrenean oak system and interactions between the two components

According to Nair's Agroforestry concept (1991), silvopastoral systems involve at least two distinct components: trees and pasture/animals. One of the main conditions of agroforestry is the existence of reciprocal benefits between the entities of the system. According to Castro (2004b), fertilisation and control of encroachment are the benefits for the tree component. On the other hand, the advantages for the animals, the other component of system, are the provision of feed and shelter. The woodlands are used by small ruminants with different purposes (feeding, transit, shelter and resting), depending on animal species and season. Details of resources used are illustrated in Fig. 6.2.

This kind of silvopastoral system represents an efficient use of resources yearround through the optimal temporal use of the resource mixing the use of an understory tree layer as a feeding resource.

During the period when the trees are in leaf (May-October), sheep flocks move through Pyrenean oak woodlands, mainly searching for shelter and to rest during the middle of the day. The resting periods take place mainly inside the woods, and resting time represents about $20-30 \%$ of sheep and goat flocks respectively of their resting (Castro et al. 2004). Fodder resource from leaves is mainly used by goat flocks. Consumption increases through the season, becoming very high in August-September, when the other resources become less abundant and of less quality. Castro et al. (2004) found the summer diet of goats contained about $25 \%$ of leaves whereas it was only $2.5 \%$ in the diet of sheep. 


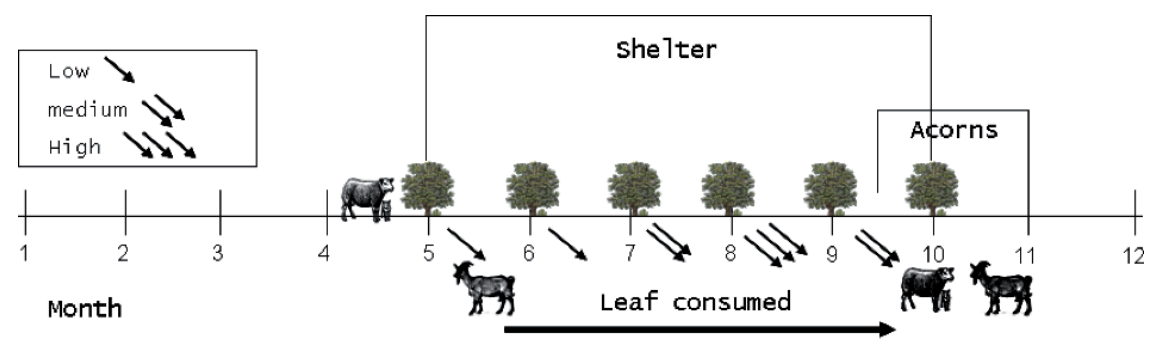

Fig. 6.2 Resources used by animals in the Pyrenean oak system during the year

Acorn production starts in late September and ceases in early November. Acorns are eaten by both sheep and goat flocks. The winter use of Pyrenean oak woodlands by sheep flocks is quite insignificant, (less than 1\%) goats spend about $10 \%$ of their time in the woodland. During the winter period flocks move through the woodlands searching for and gazing understory shrubs and grass.

\section{Chestnut Tree Systems: Coppices and Orchards}

Castanea sativa (Mill.) is a multipurpose species that is cultivated for timber production nut production, or both timber and nut production and for tannin production (Monteiro 2000). Among a large number of associated products, mushrooms have been the most valued for both fresh consumption and the food industry (ScarasciaMugnozza et al. 2000). Chestnut ecosystems also represent an important place in animal husbandry in the mountain regions.

The genus Castanea is distributed throughout the world, mainly in Asia (China, Korea and Japan), Southern Europe, Turkey and the United States. According to Pereira-Lorenzo et al. (2006), Asia is the most important chestnut growing area of the world, where Castanea mollissima Blume is found naturally as well as in cultivation. Southern Europe and Turkey are the second main area, where Castanea sativa Mill. is predominant. Castanea dentata Borkh. was naturally widespread in North-America but is now being substituted by hybrids.

Sweet chestnut (Castanea sativa Miller.) has been cultivated for centuries as coppice or orchards. It has been cultivated in northern Portugal since Roman times (Sales-Luis and Monteiro 1998). In the mountainous regions around the European Mediterranean basin and in the Southern Alps, Sweet chestnut still represents an important landscape component, covering more than 2.2 million hectares (Vogt et al. 2006).

In Portugal, chestnut forest ecosystems cover around 35,000 ha (Monteiro 2000). Coppices for timber production occupy only $10 \%$ of this area and high forest stands are unusual (Monteiro and Patrício 1996). The largest area taken up by the chestnut crop is in orchards for nut production. About $46 \%$ of the chestnut area is 
located in Northeast Portugal, in the Bragança region (Monteiro 2000). This is the origins of two Denomination de Origin Protégé (DOP) "Castanha da Terra Fria" (Ribeiro et al. 2007) and "Castanha da Padrela" (Abreu 2005).Chestnut trees can be found growing under diverse sorts of climatic conditions in Mediterranean Europe. For example, it can be found where elevation increases winter temperatures and moisture conditions (precipitation above $800 \mathrm{~mm}$ ) - mainly on northern and eastern slopes - in the transition between Mediterranean sclerophyllous forests and in the temperate deciduous forests with Quercus pyrenaica.

Nowadays, favourable market conditions for chestnuts and gradual abandonment of full-time, permanent farming have stimulated efforts to establish new orchards. Unfortunately, high mortality rates caused by diseases such as chestnut blight (Cryphonectria parasitica Murr Barr. and chestnut ink (Phytopthora sp.) affect the main areas of chestnut production in Portugal.

In the Bragança region, the chestnut orchards are frequently intercropped with cereal crops for direct consumption by sheep. The low plantation density (70-100 stems per hectare; $12 \times 12$ or $10 \times 10 \mathrm{~m}$ spacing) also allows crop cultivation for a number of years, generally producing forage for animals.

In the chestnut orchards, locally named soutos, utilization of pastures is generally limited to sheep as the soutos owners exclude goats since they can damage the bark of the trees.

Traditionally, sheep in flocks eat the chestnuts left over on the ground after the harvest. In the orchards intercropped with cereals for direct animal consumption, locally named ferrã, sheep grazing occurs during winter and part of the spring. When intercropping is absent, the coarse understory species are eaten, since the ground is less frequently ploughed.

Fruits become ripe around October-November and chestnuts are pruned every 3 years from February to March in order to increase fruiting. Regular ploughing occurs three to five times per year (Abreu 2005), mainly for weed control and facilitation of harvesting. This emphasis on ploughing has had a negative effect on the soil and has caused the spread of ink disease. Generally, these operations take place after harvesting to incorporate litter into the soil, and in spring, for weed control, and before harvesting to facilitate the collection of fruits. Some additional ploughing can be done for fertiliser incorporation. The details of resource use and cultural practices in the souto system are shown Fig. 6.3.

Chestnuts are readily eaten by animals for food. According to Pereira-Lorenzo et al. (2006) the nutritional value of chestnut varies by cultivar and by region. This author describes the composition of a large number of samples, characterised by higher starch content - between $45 \%$ and $60 \%$ of dry matter, and higher total sugars - from $13 \%$ to $20 \%$ (data refers to dry matter (DM)). The fibrous fraction is very low, with neutral detergent fibre (NDF) varying between $16 \%$ and $18 \%$ of dry matter, acid detergent fibre (ADF) between $2.7 \%$ and $3.5 \%$ and crude fibre (CF) between $2.5 \%$ and $2.9 \%$, fat compounds varying between $2.8 \%$ and $3.2 \%$ and crude protein $(\mathrm{CP})$ from $5.8 \%$ to $6.3 \%$. According to de La Montana-Míguelez et al. (2004) chestnuts cultivated over schist soils contain higher protein than those over granite based soils. 
Nowadays, farmers are strongly motivated to maintain or re-introduce silvopastoral practices, thus reducing the frequency of ploughing and its subsequent negative effects on soil and the spread of the disease. New harvesting techniques also provide space for intercropped pasture.

As for pyrenean oak, tree chestnut could also be used in silvopastoral systems when coppiced. This form of tree management was used for millennia, to regularly and intensively manage crops for fast timber production, frequently in short rotations. They are currently over-matured and most have been long abandoned (Vogt et al. 2006). In some of these areas, chestnuts from coppices are consumed by animals, mainly goats and pigs that make use of this valuable food resource. The details of resource use and cultural practices in a typical chestnut coppice system are shown in Fig. 6.4.

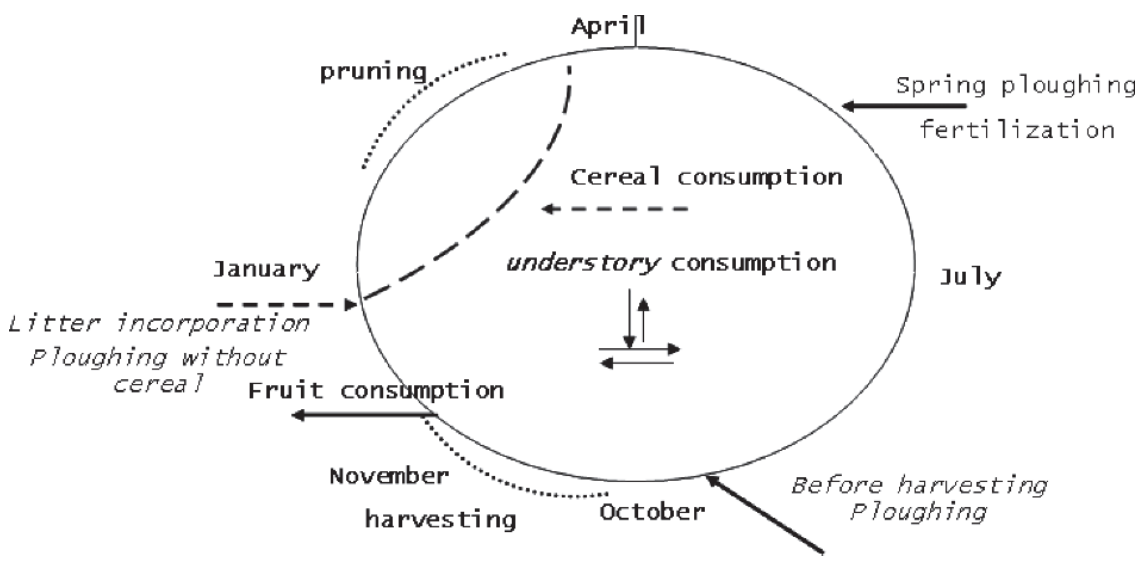

Fig. 6.3 Multipurpose use of the souto system and its functioning

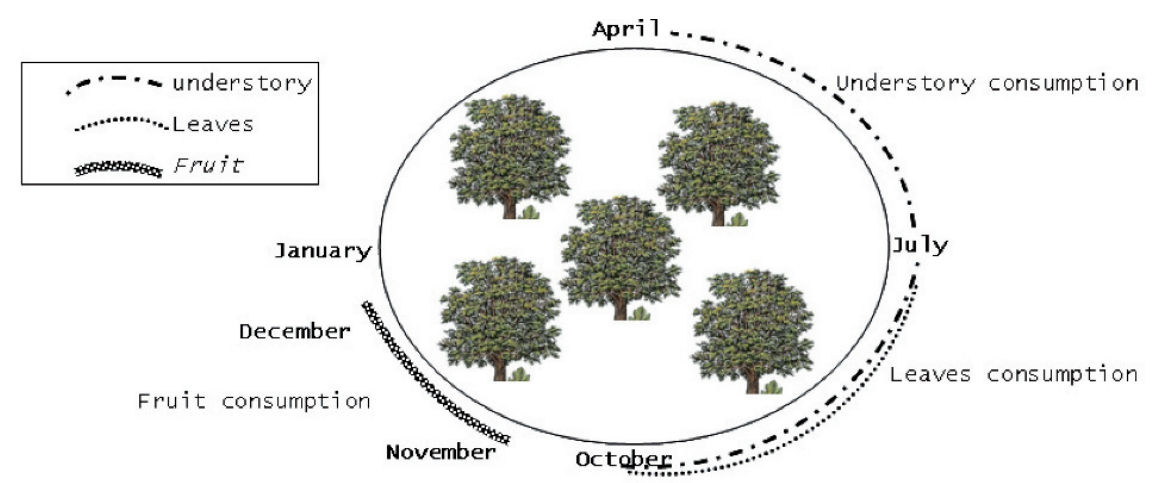

Fig. 6.4 Multipurpose use of the chestnut coppice system and its functioning 
Frequently, in chestnut coppices, the shepherds used to lop the branches to feed their animals on the fodder. Alibes and Tisserand (1990) describe seasonal variations in the nutritious value of chestnut leaves, from spring to autumn as: CP $12.4 \%$ to $14.5 \%$, NDF $33.3 \%$ to $37.5 \%$, ADF $24.7 \%$ to $26.3 \%$ and CF $18.9 \%$ to $20.9 \%$. On the other hand, shrubs and other understory plant resources can be used by the flocks of chestnut coppices.

\section{Olive Tree Systems}

Olive (Olea europeaea L.) orchards with other annual crops cultivated between the trees form a continuous landscape in many parts of southern Europe (Eichhorn et al. 2006). According to Papanastasis (2004), the olive tree (Olea europaea L.) is the most important planted evergreen species forming agrosilvopastoral systems in the Mediterranean region. Olive growing is of great economic and socio-cultural significance for the Mediterranean region, where $98 \%$ of the world's olive production is located (Kiritsakis 1998).

This system may be the most complete multipurpose form of land use in the world and delivers a large diversity of products. Olive trees can be used for both production of olives for man and foliage for animal feed. Commonly, the annual production is used for the production of olive oil and table olives (Ribeiro et al. 2007). The old and unproductive trees are used for firewood. In the past, olive oil was used for more than food. It was used in traditional medicine, pharmacy, for lighting, for religious ceremonies, etc. (Kiritsakis 1998). In the Mediterranean climatic type regions of Portugal, this system is very common. Generally olive trees are found associated with cereals or grape vines. In other areas, rye and oats are cultivated (for direct consumption by animals.

In Portugal, olive orchards cover about 340,000 ha, with 62,000 ha in northeast Portugal (Monteiro 1999).

Olive trees can be found in a wide range of climatic conditions, all over the territory of Portugal. Mediterranean conditions, with pleasant winters and an average rainfall of $450-800 \mathrm{~mm}$, is the ideal environment for this species. Olive trees do not grow in winter temperatures below $9^{\circ} \mathrm{C}$ but must be subjected to a certain amount of chilling during the winter (November-February) to enable flowering (Kiritsakis 1998). On the other hand, it is very sensitive to excessive moisture (Monteiro 1999).

The fruits become ripe around November-December (in modern varieties the mature fruits come first). Every 2-3 years, olive trees are pruned to increase fruit production. This practice takes place after fruit harvest, in February-March, and represents a large time investment in what is specialised work.

The use of by-products of this crop (mainly olive leaves) has been part of the farming tradition in the countries of the Mediterranean basin (Sansoucy et al. 1985). In diverse systems, where animals are a component of crop production, pruning provides a useful additional foodstuff, thereby reducing the cost of animal feeds. According to Delgado-Pertíñez et al. (2000) olive leaves at the moment of 


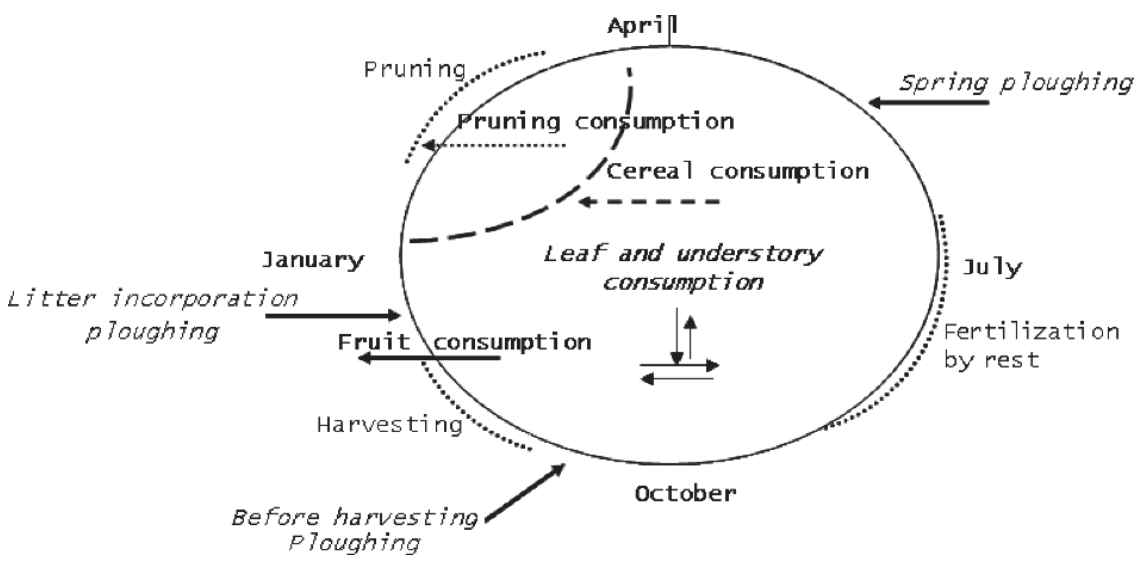

Fig. 6.5 Multipurpose use of olive orchards and its functioning

pruning have a high forage value. They consist of about $12 \%$ Crude Protein and $43 \%$ Digestible Organic Material. The details of resource use and cultural practices in the olive tree system are illustrated in Fig. 6.5.

After the commercial collection of olives, sheep and goat flocks feed on the remaining fruit left over on the ground. The understory species are grazed mainly in spring.

In ancient times, flocks slept in the olive groves during the summer to help fertilise the trees, another important component of their multipurpose use.

Traditionally, olive tree density is about 100 to 125 trees per hectare, $(9 \times 9$ or $10 \times$ $10 \mathrm{~m}$ spacing). In the more intensive systems, spacing decreases to $6 \times 6 \mathrm{~m}$ for table olive and $7 \times 7 \mathrm{~m}$ for olive oil production (Monteiro 1999). In recent years, some orchards have been planted at higher densities, with 400 trees per hectare $(7 \times 3.5 \mathrm{~m}$ spacing) or more; but multiple use is not an objective in these very intensive systems.

The soil under olive trees is ploughed two to three times per year. Farmers do not like having competitive vegetation in the orchards. This results in negative effects for the soil. Agro-environmental subsidies, which encourage the maintenance of a vegetation cover, have a positive effect by reducing the frequency of ploughing.

New practices to increase olive yields and to increase the returns on the cash crop include the use of irrigation, synthetic fertilisers, repeated short-term planting of early fruiting cultivars at high densities, and intensive use of pesticides. These more intensive systems threat the multipurpose use of olive tree systems, which are usually reduced in area.

\section{Montado Systems}

The montado is the most extensive agroforestry system in the Iberian Peninsula, occupying an area of about 3 million hectares, 2,248,000 ha in south-western Spain and 869,000 ha in southern Portugal (Eichhorn et al. 2006). It represents a man-made 
ecosystem which is dependent on human practices and management for its conservation (Joffre et al. 1999). The montado is characterized by the presence of an open tree layer, mainly dominated by Mediterranean evergreen oaks - holm oak (Quercus ilex L.) or cork oak (Quercus suber L.) - and to a lesser extent, by deciduous oaks (Quercus pyrenaica and Quercus faginea Lam.). The understory herbaceous vegetation is dominated by winter annuals and to a lesser extent by small evergreen shrubs (Vicente and Alés 2006). The general structure is similar to tropical savannahs (Joffre et al. 1999).

The Montado system occurs under the Mediterranean climate, long and dry summers where the temperature often reaches $30-40^{\circ} \mathrm{C}$, with an average precipitation of 500-650 mm irregularly distributed, concentrated in the period October-March, and with important annual (interannual and intraanual) fluctuations of precipitation (Correia 1993). Cork oak dominates in the coastal areas where the oceanic influence is stronger, while the holm oak is characteristic of the driest areas. Hence Portugal has a larger area of Cork oak than Spain, and the main area of holm oak is in the interior of the Iberian Peninsula.

Generally, in the Portuguese literature, the term montado is synonymous with Spanish dehesa. Nevertheless, this is not absolutely correct. According to Vicente and Alés (2006), the term dehesa comes from the Latin word defesa (protected), and it means "enclosed". Until the 20th century, it has meant private grazing land, with no reference to any vegetation type. These authors showed that the term dehesa - grasslands with scattered trees, where shrubs have been mostly eliminated (Spanish Society for Pasture Research - SEEP) - has been used since the forties.

Dehesa has a dual meaning, as a vegetation type and as private grazing land. Montado (Dictionary of Portuguese Academy of Language) is a land use generally dominated by Quercus suber or Quercus ilex where pigs graze. The term montanheira, originating from montado, means the practice of acorn grazing by pigs, supporting this designation. Montado and Dehesa have not the same origin.

Both terms - montados and dehesas - mean a multi-propose agroforestry system with an open tree layer above a grass layer which depends on human practices and management.

The cork or holm oak stands frequently occurring in the Trás-os-Montes Province are not a montado, because the agro-pastoral component is not present. In this case, they are called cork oak stands or cork oak forest.

This system of land use may have been practised for up to 4,500 years (Stevenson and Harrison 1992) as a result of the progressive transformation of pristine forest into more productive land-use based on a selection of trees - "the frutalization the oak woodlands" (González-Bernáldez 1995). This transformation leads to a landuse system based on the diversity and complementarily of production (PintoCorreia 2000).

In the traditional montado, the herbaceous layer has been maintained by cereal cultivation over long rotations. Regular ploughing is necessary as an efficient method to avoid shrub colonisation. More recently, this practice has been associated with the spread of cork oak diseases (Castro 1998). 
According to Pinto-Correia and Mascarenhas (1999), tree cover does not follow a regular pattern, and densities vary from 20 to 80 trees per hectare. Jofre et al. (1991) reported 40 to 50 stems per hectare. Usually, in the cork montado, tree density is higher than in holm montado. In the first case, the main product is cork, while in the second, the aim is to maximise acorn production for feeding livestock.

Cork and holm oak trees have a direct value as a fodder crop, providing acorns and leafy branches, and indirect value as shelter for cold in winter and heat in summer (Vicente and Alés 2006). Acorns are eaten by livestock when they fall during the autumn and winter. At this time there is a need for supplementing animal diets and when there is a relative herb shortage (Pulido et al. 2001). The trees were periodically pruned to further enhance acorn production and its branches provide also a useful additional feed.

In ancient times, before the development of fossil fuels, holm oak was also highly valued for charcoal production. In more recent times, the income from forestry practices (pruning, thinning) was marginal for the household economy (Díaz et al. 1997). Nowadays, only cork production is highly valued, among the forest products of the montado.

Portugal is the major world cork producer, with an average annual production of approximately 190,000t, which corresponds to about half of the world production (Leal et al. 2006). Portuguese conditions mean that cork bark can be removed in cycles of 9 years (Pinto and Torres-Pereira 2006). Cork products represent $3 \%$ of Portugal's exports.

The Cork oak area in Portugal is 725,000 ha and in Spain 475,000 ha (Pereira and Tomé 2004). These areas include montados and forest stands. However, some authors have reported that the development of plastic screw caps for wine bottles will threaten the cork industry in the future. Fortunately, the resurgence of a wine culture, and also the demand for quality products, will protect the market for genuine cork wine bottle stoppers.

The traditional system was highly diversified in terms of livestock types (sheep, goats, pigs and cattle). In Portugal, the indigenous pig was the most common animal in the Montado, before African swine disease arrived in the late 1950s. Recently, Portuguese montados used to be rented by Spanish pig owners for montanheira. On the other hand, Spanish wild cattle for bullfighting are a key income of the dehesa, but its importance is incomparably low in Portugal.

Joffre et al. (1999) reported that pigs graze the seasonal acorn production, between October and February, gaining about $60 \mathrm{~kg}$ live weight over 75 days. Rupérez (1957) reported that $9 \mathrm{~kg}$ of Quercus ilex acorns corresponds to the production of $1 \mathrm{~kg}$ of pork meat.

Today, montado has a renewed relevance due its environmental value. This system has been qualified, together with the remains of lightly used Mediterranean forests, as habitats to be preserved within the EU Habitats Directive because of the high biological diversity that they support (Pulido et al. 2001).

As for the other systems, the size of private property has an essential role in the functioning of montado systems. The relationship between property size and degree of autonomy of systems is marked (Fig. 6.6). 


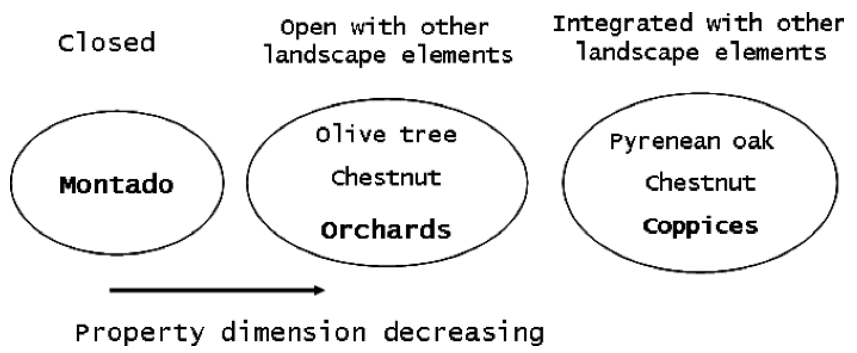

Fig. 6.6 Relationship between type of silvopastoral systems and land tenure

\section{Conclusions}

A broad outline of trends in silvopastoral systems has been described. There are gaps in knowledge of these land uses and these require more research about them.

Agroforestry systems are related to the environment, culture and history of the Mediterranean basin. Their geographical distribution is related to primary production, where it is limited by drought or coldness, but also where agricultural specialization was not possible.

Both systems studied (typically Mediterranean and environmental transitional) have comparable functions: all possible food resources are utilised by animals, and the role of grazing is in soil fertilisation and shrub encroachment control. Trees provide additional incomes from direct trade of products such as cork, firewood, or fruit production, as well as benefiting the soil structure, nutrient content, and soil protection. The main practices with trees are reported: pruning and ploughing are common for all systems and increase fructification. In Pyrenean oak and chestnut coppices, thinning is the only tree operation reported.

The maintenance of these extensive systems appears to need support by future Common Agricultural Policy (CAP) measures.

\section{References}

Abreu CG (2005) Detecção remota da doença da tinta e cadastro da área de castanheiro na Terra Fria de Bragança e Padrela por fotografia aérea de infravermelho próximo. UTAD, ESAB, DRATM, ARATM, ARBOREA, Vila Real, Portugal

Alibes X, Tisserand JL (eds.) (1990) Tableaux de la valeur alimentaire pour les ruminants des fourrages et sous-produits d'origine Méditerranéenne. CIHEAM-IAMZ, Zaragoza, Spain

Calvo L, Santalla S, Marcos E, Valbuena L, Tarrega R, Luis E (2003) Regeneration after wildfire in communities dominated by Pinus pinaster, an obligate seeder, and in others dominated by Quercus pyrenaica, a typical resprouter. Forest Ecol Manag 184:209-223

Carvalho JPF (1995) A Quercus pyrenaica Willd. e a condução dos seus povoamentos. Provas de Aptidão Pedagógica e Capacidade Científica. UTAD, Vila Real, Portugal

Castro JF (2004a) Análisis de la evolución reciente del paisaje rural de Trás-os-Montes, Portugal: el caso de los retículos arbóreos en la matriz agrícola. Tesis Doctoral. Universidad de Alcalá de Henares, Spain 
Castro M (1998) Etude comparative de deux surfaces fourrageres dans un systeme agroforestier: valeur nutritive et utilisation de la vegetation par les animaux. Thèse Master. ENSAM/ AGROPOLIS, Montpellier, France

Castro M (2004b) Análisis de la Interacción vegetación-herbívoro en sistemas silvo-pastorales basados en Quercus pyrenaica. Tesis Doctoral. Universidad de Alcalá de Henares, Spain

Castro M, Castro JF, Esteves A, Teixeira A, Gómez-Sal A (2000a) Les parcours annuels des troupeaux d'ovins dans la région de montagne de Trás-os-Montes e Alto Douro, au Portugal. In: Guessous F, Rihani N, Ilham A (eds.) Livestock production and climatic uncertainty in the Mediterranean. Wageningen Pers, Wageningen, The Netherlands

Castro M, Vinagre P, Esteves A, Castro JF (2000b) Caracterização dos percursos de pastoreio de ovinos e caprinos no nordeste de Portugal. In: $3^{\text {a }}$ Reunião Ibérica de Pastagens e Forragens, Bragança. Lugo, A Coruña, Spain

Castro M, Castro JF, Gómez-Sal A (2004) Quercus pyrenaica Willd. woodlots and small ruminants production in Northeast Portugal. In: Schnabel S, Ferreira A (eds.) Sustainability of agrosilvopastoral systems -dehesas, montados-. Catena Verlag, Reiskirchen, Germany

Corcuera L, Camarero JJ, Sisó S, Gil-Pelegrín E (2006) Radial-growth and wood-anatomical changes in overaged Quercus pyrenaica coppice stands: functional responses in a new Mediterranean landscape. Trees 20:91-98

Correia TP (1993) Threatened landscape in Alentejo, Portugal: the 'montado' and other 'agrosilvo-pastoral' systems. Landscape Urban Plan 24:43-48

Debussche M, Debussche G, Lepart J (2001) Changes in the vegetation of Quercus pubescens woodland after cessation of coppicing and grazing. J Veg Sci 12:81-92

De La Montana-Míguelez J, Miguez-Bernardez M, Garcia-Queijeiro JM (2004) Composition of varieties of chestnuts from Galicia (Spain). Food Chem 84:401-404

Delgado-Pertíñez M, Gómez-Cabrera A, Garrido A (2000) Predicting the nutritive value of the olive leaf (Olea europaea): digestibility and chemical composition and in vitro studies. Anim Feed Sci Tech 87:187-201

De Miguel JM (1999) Naturaleza y configuración del paisaje agrosilvopastoral en la conservación de la diversidad biológica en España. Revista Chilena de Historia. Natural 72:547-557

Díaz M, Campos P, Pulido FJ (1997) The Spanish dehesa: a diversity in land use and wildlife. In: Pain DJ, Pienkowski MW (eds.) Farming and birds in Europe. The Common agricultural policy and its implications for bird conservation. Academic, London

Eichhorn MP, Paris P, Herzog F, Incoll LD, Liagre F, Mantzanas K, Mayus M, Moreno G, Papanastasis VP, Pilbeam DJ, Pisanelli A, Dupraz C (2006) Silvoarable systems in Europe past, present and future prospects. Agroforest Syst 67:29-50

Etienne M (1996) Research on temperate and tropical silvopastoral systems: a review. In: Western European silvopastoral systems. INRA, Paris

Franco JA (1956) O carvalho negral: subsidios para o seu estudo botânico-florestal. Dissertação para Professor Extraordinario. Instituto Superior de Agronomia, Lisbon, Portugal

Gómez-Sal A (2000a) The variability of Mediterranean climate as an ecological condition of livestock production systems. In: Ilham A (ed) Livestock production and climatic uncertainty in the Mediterranean. Wageningen Pers, Wageningen, The Netherlands, pp. 3-11

Gómez-Sal A (2000b) Las razas de ganado autóctono en la conservación de la naturaleza. In: Rodríguez F (ed) Manual del técnico en medio ambiente natural. Colegio de Veterinarios de Ourense, Ourense, Spain

González-Bernáldez F (1995) Western Mediterranean land-use systems as antecedents for semiarid America. In: Turner II BL, Gómez-Sal A, González Bernáldez F, Di Castri F (eds.) Global land use change: a perspective from the Columbian encounter. CSIC, Madrid, pp 131-149

INMG (1991) O clima de Portugal. Normas climatológicas da região de "Trás-os-Montes e Alto Douro" e "Beira Interior", correspondentes a 1951-1980. INMG, Lisboa

INMG (2006) Perfil Climático - Portugal Continental: Clima 1961-1990. http://www.meteo.pt/pt/ clima/. Cited 12 Nov 2006

Jofre R, Hubert B, Meuret M (1991) Les systèmes Agro-Sylvo-Pastoraux Méditerranéens: Enjeux et réflexiones pour une gestion raisonnée. UNESCO, Paris 
Joffre R, Rambal S, Ratte JP (1999) The dehesa system of southern Spain and Portugal as a natural ecosystem mimic. Agroforest Syst 45:57-79

Kiritsakis AK (1998) Olive oil from the tree to the table, $2^{\mathrm{a}}$ edition. Food and Nutrition Press, Trumbull, CT

Leal S, Sousa VB, Pereira H (2006) Within and between-tree variation in the biometry of wood rays and fibres in cork oak (Quercus suber_L.). Wood Sci Technol 40:585-597

Lopez-Bote CJ (1998) Sustained utilization of the Iberian pig breed. Meat Science Meat Consumption and Culture. 44th Int Cong Meat Sci Technol 49:S17-S27

Monteiro AM (1999) A oliveira. João Azevedo publisher, Mirandela, Portugal

Monteiro ML (2000) Trás-os-Montes um lugar de Castanheiros. In: Pereira R (ed) Florestas de Portugal. Direcção Geral das Florestas, Lisboa

Monteiro ML, Patrício MS (1996) O castanheiro - modelos de gestão. Revista Florestal IX(4):51-56

Nair PKR (1991) State-of-the-art of agroforestry systems. In: Jarvis PG (ed) Agroforestry: principles and practices. Elsevier, Amsterdam

Nair PKR (1993) An introduction to agroforestry. Kluwer, Dordrecht, The Netherlands

Papanastasis V (2004) Vegetation degradation and land use changes in agrosilvopastoral systems. In: Schnabel S, Ferreira A (eds.) Sustainability of agrosilvopastoral systems - dehesas, montados, vol 37. Advances in Geoecology 37. Catena Verlag, Reiskirchen, Germany, pp 1-12

Pereira H, Tomé M (2004) Cork oak. In: Burley J, Evans J, Youngquist JA (eds.) Encyclopedia of forest sciences. Elsevier/Academic, Oxford

Pereira-Lorenzo S, Ramos-Cabrer AM, Diaz-Hernandez MB, Ciordia-Ara M, Rios-Mesa D (2006) Chemical composition of chestnut cultivars from Spain. Sci Hortic-Amsterdam 107:306-314

Pinto TM, Torres-Pereira JMG (2006) Bark stripping in cork oak (Quercus suber L.): effect of an antitranspirant application on gas exchange and water relations of the stripped surface. Tree 20:247-252

Pinto-Correia T (2000) Future development in Portuguese rural areas: how to manage agricultural support for landscape conservation? Landscape Urban Plan 50:95-106

Pinto-Correia T, Mascarenhas J (1999) Contribution to the extensification/intensification debate: new trends in the Portuguese montado. Landscape Urban Plan 46:125-131

Pulido FJ, Diaz M, Hidalgo de Trucios SJ (2001) Size structure and regeneration of Spanish holm oak (Quercus ilex) forests and dehesas: effects of agroforestry use on their long-term sustainability. Forest Ecol Manag 146:1-13

Ribeiro B, Rangel J, Valentao PXC, Andrade PB, Pereira JA, Bolke H, Seabra RM (2007) Organic acids in two Portuguese chestnut (Castanea sativa Miller) varieties. Food Chem 100:504-508

Rupérez A (1957) La encina y sus tratamientos. Ediciones Selvícolas, Madrid

Sales-Luis JF, Monteiro ML (1998) Dynamics of a broadleaved (Castanea sativa) conifer (Pseudotsuga menziesii) mixed stands in Northern Portugal. Forest Ecol Manag 107:183-190

San-Miguel A, Roig S, Cañellas I (2002) Las prácticas agroforestales en la Península Ibérica. Cuad Soc Esp Cien For 14:33-38

Sansoucy RAX, Martilotti F, Nefzaoui A, Zoiopoulos P (1985) Los Subproductos del Olivar en la Alimentación Animal en la Cuenca del Mediterráneo. FAO, Roma

Santa-Regina I (2000) Biomass estimation and nutrient pools in four Quercus pyrenaica in Sierra de Gata Mountains, Salamanca, Spain. Forest Ecol Manag 132:127-141

Scarascia-Mugnozza G, Oswald H, Piussi P, Radoglou K (2000) Forests of the Mediterranean region: gaps in knowledge and research needs. Forest Ecol Manag 132:97-109

Stevenson AC, Harrison RJ (1992) Ancient forest in Spain: a model for land-use and dry forest management in South-West Spain from 4000 BC to 1900 AD. P Prehist Soc 58:227-247

Tarrega R, Calvo L, Marcos E, Taboada A (2006) Forest structure and understory diversity in Quercus pyrenaica communities with different human uses and disturbances. Forest Ecol Manag 227:50-58

Vicente AM, Alés RF (2006) Long term persistence of dehesas. Evidences from history. Agroforest Syst 67:19-28

Vogt J, Fonti P, Conedera M, Schroder B (2006) Temporal and spatial dynamic of stool uprooting in abandoned chestnut coppice forests. Forest Ecol Manag 235:88-95 